\title{
ANALISIS TINGKAT KEMAMPUAN BERPIKIR KRITIS DENGAN MODEL PERUBAHAN KONSEPTUAL DITINJAU DARI GAYA BELAJAR SISWA
}

\author{
Dedi Riyan Rizaldi*, Muh. Makhrus, Aris Doyan \\ Program Studi Pendidikan Fisika, Universitas Mataram \\ *Email: dedi0313@gmail.com
}

DOI: http://dx.doi.org/10.29303/jpft.v5i1.794

\begin{abstract}
This study aims to determine the level of critical thinking ability when learning process on kinetic theory of gas with the conceptual change model outcome review from high school student learning style. This type of research is pre-experiment with factorial design $3^{2}$ (level 3). The research population is all grade XI IPA in SMA Negeri 7 Mataram with sampling technique using purposive sampling. Three samples were taken as an experimental class which is class XI MIPA 1 taught with CCM visual style, XI IPA 2 taught by CCM auditory style, and XI IPA 3 taught with CCM kinesthetic style. The student learning style data on was taken using by questionnaire with four alternative options. The critical thinking ability's data collected by using sheets of critical thinking skill based on the student's answer to LKS. The result data were analyzed with descriptive statistical test and classified based on the categorization level of critical thinking ability. Based on the analysis result, it can be concluded the level of critical thinking ability when learning process kinetic theory of gas with conceptual change model outcome review from high school student learning style including into medium category with a value of 70,87 .
\end{abstract}

Keywords: Conceptual Change Model (CCM), Level of Critical Thinking, Learning Styles.

\section{PENDAHULUAN}

Berpikir merupakan suatu aktivitas dalam diri seseorang jika dihadapkan pada suatu permasalahan yang harus dipecahkan. Kemampuan berpikir merupakan salah satu bagian terpenting yang harus dilatih pada diri siswa saat proses pembelajaran berlangsung. Purwanto (1992) menjelaskan bahwa belajar merupakan perubahan yang terjadi melalui proses latihan atau pengalaman yang didapatkan seseorang. Proses belajar memberikan pengalaman baik berupa kemampuan, keterampilan, strategi, dan nilai yang membantu seseorang dalam kehidupan sehari-hari (Gredler, 2011). Guru sangat diharapkan mampu menerapkan pembelajaran yang dapat melatih kemampuan berpikir siswa, salah satunya yaitu kemampuan berpikir kritis.

$$
\text { Berpikir kritis merupakan }
$$

perwujudan dari berpikir tingkat tinggi (higher order thinking) karena kemampuan berpikir kritis dapat dipandang sebagai kemampuan berpikir siswa untuk membandingkan dua atau lebih informasi yang dimiliki. Facione (2011) menyatakan bahwa berpikir kritis adalah suatu pendekatan terhadap suatu permasalahan dan persoalan terbaru. Latihan dalam menyelesaikan berbagai permasalahan yang ditemukan akan meningkatan kemampuan berpikir kritis (Fatimah et al. 2016)

$$
\text { Lebih jelas Gunawan }
$$
menyatakan bahwa berpikir kritis adalah proses disiplin yang secara intelektual aktif dan terampil mengkonseptualisasi, menerapkan, menganalisis, mengsintesis, dan mengevaluasi informasi yang dikumpulkan dari atau dihasilkan oleh pengamatan, pengalaman, refleksi, penalaran, atau komunikasi, sebagai panduan untuk kepercayaan dan tindakan. Kemampuan berpikir kritis ini harus dimiliki siswa yang dapat dijadikan sebagai modal penting dalam mempelajari sesuatu khususnya materi pembelajaran yang rumit seperti konsep-konsep dalam ilmu fisika. Indikator kemampuan berpikir kritis yang digunakan diadaptasi dari Facione (2011) 
yaitu interpretasi, analisis, evaluasi, inferensi, dan penjelasan.

Teori kinetik gas merupakan salah satu materi fisika yang dipelajari di tingkat SMA yang membutuhkan kemampuan analisis tingkat tinggi. Vegisari (2015) menyatakan bahwa materi teori kinetik gas bersifat abstrak karena membahas tentang gas ideal yang pada hakekatnya tidak ada dan hanya sebagai asumsi sehingga menyebabkan siswa terkadang sulit untuk bisa menerima materi yang dipelajari saat proses pembelajaran berlangsung. Materi ini sangat tepat jika diajarkan dengan model pembelajaran yang dapat melatih kemampuan berpikir kritis siswa saat proses pembelajaran berlangsung. Pembelajaran yang diharapkan mampu melatih kemampuan berpikir kritis saat proses pembelajaran adalah model perubahan konseptual.

Model perubahan konseptual menurut Posner et al. (1982) merupakan suatu pembelajaran yang melibatkan perubahan konsep seseorang disamping menambah pengetahuan baru dengan pengetahuan yang dimilikinya. Model perubahan konseptual yang digunakan adalah model Driver. Posner menyatakan bahwa kondisi-kondisi yang harus dipenuhi agar perubahan konseptual dapat terjadi pada diri siswa terlihat dalam model Driver (Dahar, 2011). Model Driver terdiri dari lima fase pembelajaran yaitu orientasi, elisitasi gagasan, restrukturasi gagasan, aplikasi gagasan, dan review perubahan gagasan.

Faktor lain yang menjadi kunci keberhasilan dalam belajar menurut Prashning (2007) adalah mengetahui gaya belajar unik dari setiap orang, menerima kekuatan sekaligus kelemahan diri sendiri, dan sebanyak mungkin menyesuaikan preferensi pribadi dalam setiap situasi pembelajaran yang dialami individu (dalam Rohman dan Amri, 2012). Gaya belajar ini didasarkan pada kebiasaan belajar seseorang yang paling efisien dan efektif dalam menerima, memproses, menyimpan dan mengeluarkan sesuatu yang dipelajari. Guru yang memperhatikan gaya belajar siswa akan memiliki kelebihan yaitu mengetahui kesulitan-kesulitan pada siswa dalam mempersepsi dan memproses konsepkonsep yang dipelajari.

\section{METODE PENELITIAN}

Penelitian ini menggunakan jenis pra eksperimen. Penelitian jenis ini adalah rancangan penelitian untuk mengetahui hubungan sebab-akibat yang hanya menggunakan kelompok eksperimen saja, tanpa kelompok kontrol (pembanding) (Sugiyono, 2013). Desain penelitian yang digunakan yaitu faktorial desain $3^{2}$ (taraf 3 ), dengan menggunakan tiga kelas eksperimen.

Populasi pada penelitian ini adalah seluruh siswa kelas XI IPA di SMAN 7 Mataram. Teknik pengambilan sampel yang digunakan adalah purposive sampling, sehingga didapatkan kelas XI IPA 1 sebagai kelas eksperimen 1 diajarkan dengan MPK Visual (gaya belajar visual lebih dominan dibandingkan gaya belajar lainnya). Proses pembelajaran pada kelas MPK Visual, guru akan lebih banyak menyampaikan materi atau informasi dengan berbantuan gambar, video, dan aplikasi PHET. Kelas XI IPA 2 sebagai kelas eksperimen 2 diajarkan dengan MPK Auditori (gaya belajar auditori lebih dominan dibandingkan gaya belajar lainnya).

Proses pembelajaran pada kelas MPK Auditori, guru menyampaikan materi secara langsung dengan berbicara satu arah atau ceramah. Kelas XI IPA 3 sebagai kelas eksperimen 3 diajarkan dengan MPK Kinestetik (gaya belajar kinestetik lebih 
dominan dibandingkan gaya belajar lainnya).

Tabel 1. Rancangan Desain Penelitian $3^{2}$

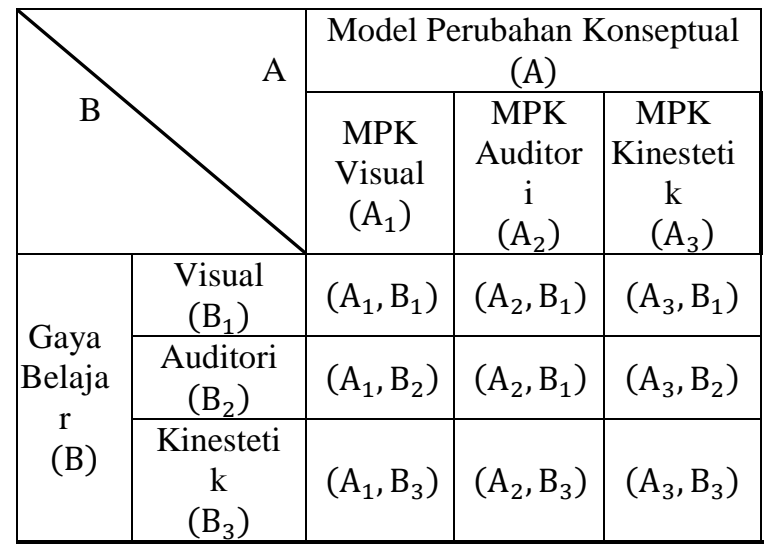

(Diadaptasi dari Aji dan Dasari, 2009)

Proses pembelajaran pada kelas MPK Kinestetik dilakukan dengan menerapkan percobaan-percobaan sederhana pada saat proses pembelajaran berlangsung. Rancangan penelitian faktorial desain $3^{2}$ dapat dilihat pada Tabel 1 . Teknik analisis data menggunakan persamaan sebagai berikut.

$$
\text { nilai }=\frac{\text { skor yang diperoleh }}{\text { skor maksimal }} \times 100
$$

Data kemampuan berpikir kritis yang didapat kemudian diklasifikasikan ke dalam Tabel 2 berikut ini

Tabel 2. Pedoman Kategori Berpikir Kritis

\begin{tabular}{cc}
\hline Skala Perolehan & Kategori \\
\hline $81,25<\mathrm{x} \leq 100$ & Sangat Tinggi \\
$71,50<\mathrm{x} \leq 81,25$ & Tinggi \\
$62,50<\mathrm{x} \leq 71,50$ & Sedang \\
$43,75<\mathrm{x} \leq 62,50$ & Rendah \\
$0<\mathrm{x} \leq 43,75$ & Sangat Rendah \\
\hline & (Sumber: Karim, 2015)
\end{tabular}

\section{HASIL DAN PEMBAHASAN}

\section{A. Hasil Penelitian}

Data penelitian diperoleh berdasarkan dari jawaban siswa pada Lembar Kerja Siswa (LKS) yang diberikan dan dinilai menggunakan lembar penilaian kemampuan berpikir kritis. LKS yang diberikan dikembangkan berdasarkan dari indikator kemampuan berpikir kritis yaitu interpretasi, analisis, evaluasi, inferensi, dan menjelaskan. Nilai yang diperoleh masingmasing kelas eksperimen untuk kemampuan berpikir kritis siswa saat proses pembelajaran berlangsung dapat dilihat pada Tabel 3 sebagai berikut.

Tabel 3. Data Kemampuan Berpikir Kritis pada saat Proses Pembelajaran

\begin{tabular}{|c|c|c|c|c|c|c|c|c|}
\hline \multirow{2}{*}{ Kelas } & \multirow{2}{*}{$\begin{array}{c}\text { Materi Pertemuan } \\
\text { Ke- }\end{array}$} & \multicolumn{5}{|c|}{ Tingkat Kemampuan Berpikir Kritis } & \multirow{2}{*}{$\begin{array}{l}\text { Rata- } \\
\text { rata }\end{array}$} & \multirow{2}{*}{ Kategori } \\
\hline & & $\mathrm{A}$ & B & $\mathrm{C}$ & $\mathrm{D}$ & $\mathrm{E}$ & & \\
\hline Eksp. 1 & 1 & 95,40 & 84,30 & 75,90 & 63,00 & 63,00 & 76,00 & Tinggi \\
\hline Gaya & 2 & 100,00 & 69,30 & 66,70 & 72,60 & 78,60 & 77,00 & Tinggi \\
\hline Visual & 3 & 50,00 & 75,80 & 62,50 & 72,10 & 66,30 & 65,00 & Sedang \\
\hline Eksp. 2 & 1 & 71.20 & 82.70 & 57.70 & 78.30 & 64.40 & 69.00 & Sedang \\
\hline Gaya & 2 & 73.10 & 62.80 & 59.30 & 75.30 & 75.90 & 66.00 & Sedang \\
\hline Auditori & 3 & 67.00 & 73.40 & 68.50 & 82.40 & 73.10 & 72.00 & Tinggi \\
\hline Eksp. 3 & 1 & 83,90 & 75,90 & 67,00 & 83,90 & 70,50 & 76,00 & Tinggi \\
\hline Gaya & 2 & 83,00 & 79,50 & 82,10 & 69,60 & 75,00 & 78,00 & Tinggi \\
\hline Kinestetik & 3 & 50,00 & 78,30 & 63,40 & 70,50 & 70,50 & 66,00 & Sedang \\
\hline
\end{tabular}

Keterangan :

$\begin{array}{lll}\mathrm{A} & \mathrm{:} & \text { Interpretasi } \\ \mathrm{B} & \mathrm{:} & \text { Analisis } \\ \mathrm{C} & : & \text { Evaluasi } \\ \mathrm{D} & : & \text { Menjelaskan } \\ \mathrm{E} & : & \text { Inferensi }\end{array}$

Nilai rata-rata tingkat kemampuan berpikir kritis saat proses pembelajaran pada ketiga kelas eksperimen berdasarkan materi pembelajaran yang diajarkan dapat dilihat pada Gambar 1. Berdasarkan Gambar 1, terlihat bahwa siswa pada kelas MPK Visual dan MPK Kinestetik memiliki tingkat kemampuan berpikir kritis yang lebih tinggi 
dibandingkan kelas MPK Auditori pada saat belajar tentang materi persamaan keadaan gas ideal (pertemuan 1) dan teori kinetik gas (pertemuan 2). Pertemuan 3, ketika membahas materi teori ekipartisi energi terlihat bahwa siswa kelas MPK Auditori memiliki tingkat kemampuan berpikir kritis yang lebih baik jika dibandingkan dua kelas eksperimen lainnnya.

Tingkat kemampuan berpikir kritis saat proses pembelajaran di ketiga kelas eksperimen termasuk ke dalam kategori tinggi $(71,50<\mathrm{x} \leq 81,25)$ dan sedang $(62,50<$ $\mathrm{x} \leq 71,50)$. Model pembelajaran yang sama namun dengan gaya belajar berbeda membuat kemampuan siswa dalam menerima dan menerapkan materi pada saat proses pembelajaran berbeda.

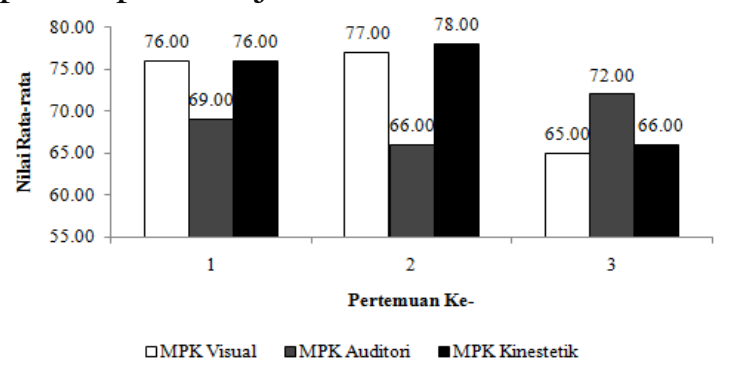

Gambar 1. Nilai Rata-rata Kemampuan Berpikir Kritis Siswa saat Proses Pembelajaran

Nilai rata-rata tingkat kemampuan berpikir kritis saat proses pembalajaran pada ketiga kelas eksperimen berdasarkan masing-masing indikator kemampuan berpikir kritis dapat dilihat pada Gambar 2 . Gambar 2 memperlihatkan pada kelas MPK Visual bahwa nilai rata-rata indikator interpretasi lebih tinggi dibandingkan indikator lainnya dengan nilai sebesar 81,80. Indikator menjelaskan pada kelas MPK Auditori lebih besar daripada indikator lainnya sebesar 78,60. Indikator analisis pada kelas MPK Kinestetik memiliki nilai rata-rata lebih tinggi dibandingkan indikator lainnya sebesar 77,90.

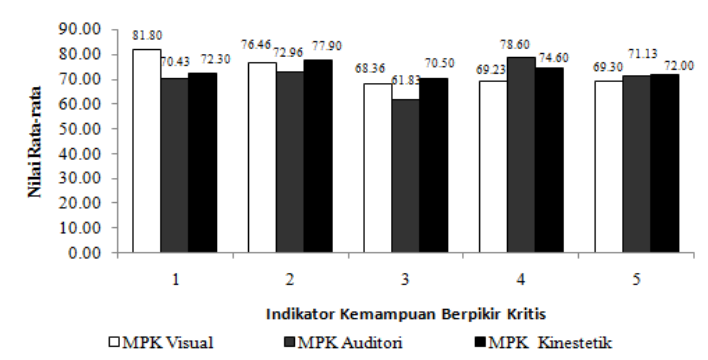

Gambar 2. Nilai Rata-rata per Indikator Kemampuan Berpikir Kritis Siswa saat Proses Pembelajaran

Berdasarkan penelitian yang dilakukan diketahui bahwa siswa dengan tipe gaya belajar visual pada kelas MPK Visual dan MPK Kinestetik memiliki ratarata nilai kemampuan berpikir kritis pada proses pembelajaran yang lebih tinggi dibandingkan dengan tipe gaya belajar lain. Siswa dengan tipe gaya belajar auditori pada kelas MPK Auditori memiliki rata-rata nilai kemampuan berpikir kritis pada proses pembelajaran yang lebih tinggi dibandingkan dengan tipe gaya belajar lain. Nilai rata-rata kemampuan berpikir kritis saat proses pembelajaran pada ketiga kelas eksperimen ditinjau dari tipe gaya belajar dari siswa secara dapat dilihat pada tabel sebagai berikut.

Tabel 4. Data Kemampuan Berpikir Kritis Siswa pada saat Proses Pembelajaran ditinjau dari Gaya Belajar

\begin{tabular}{lccc}
\hline \multirow{2}{*}{ Kelas } & \multicolumn{3}{c}{ Nilai Rata-rata } \\
\cline { 2 - 4 } & Visual & Auditori & Kinestetik \\
\hline $\begin{array}{l}\text { Eksperimen 1 } \\
\text { (MPK Visual) }\end{array}$ & 76,00 & 73,00 & 68,00 \\
\hline $\begin{array}{l}\text { Eksperimen 2 } \\
\text { (MPK }\end{array}$ & 68,50 & 70,20 & 63,60 \\
Auditori) & & 72,00 & 72,20 \\
\hline $\begin{array}{l}\text { Eksperimen 3 } \\
\text { (MPK } \\
\text { Kinestetik) }\end{array}$ & 74,40 & 70 \\
\hline
\end{tabular}

Berdasarkan Tabel 4, terlihat bahwa nilai rata-rata tertinggi tipe gaya belajar pada ketiga kelas eksperimen berbeda-beda. Nilai rata-rata tertinggi pada kelas eksperimen 1 dengan MPK Visual berada pada kelompok siswa yang memilki tipe gaya belajar visual sebesar 76,00. Nilai rata-rata tertinggi pada 
kelas eksperimen 2 dengan MPK Auditori berada pada kelompok siswa yang memiliki tipe gaya belajar auditori sebesar 70,20. Nilai rata-rata tertinggi pada kelas eksperimen 3 dengan MPK Kinestetik berada pada kelompok siswa yang memilki tipe gaya belajar visual sebesar 74,40 . Nilai rata-rata kemampuan berpikir kritis saat proses pembelajaran pada ketiga kelas eksperimen ditinjau dari tipe gaya belajar dari siswa dapat dilihat pada Gambar 3 sebagai berikut.

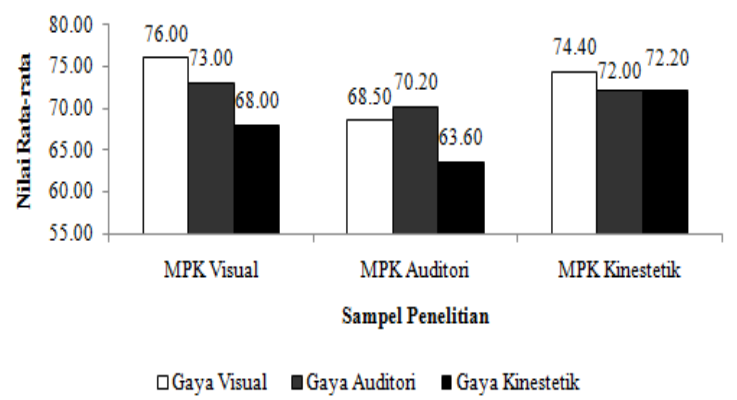

Gambar 3. Nilai Rata-rata Kemampuan Berpikir Kritis Siswa ditinjau dari Gaya Belajar pada Proses Pembelajaran

\section{B. Pembahasan}

Data yang diperoleh dalam penelitian ini adalah tingkat kemampuan berpikir kritis siswa kelas XI pada saat proses pembelajaran teori kinetik gas berlangsung. Berdasarkan Tabel 2, terlihat bahwa tingkat kemampuan berpikir kritis siswa pada semua kelas berada pada kategori tinggi dan Sedang. Tingkat kemampuan berpikir kritis yang dimiliki siswa saat proses pembelajaran di dalam kelas ini tentunya akan berdampak pada hasil belajar siswa.

Model perubahan konseptual merupakan model yang berusaha merubah konsepsi awal siswa yang tidak tepat (miskonsepsi) agar sesuai dengan konsepsi ilmiah yang ada. Perubahan konseptual dapat terjadi karena adanya perbedaan antara pengalaman belajar sebelumnya dengan konsep fisika dalam menyelesaikan permasalahan yang diberikan (Makhrus, 2018). Model ini tepat digunakan untuk mengajarkan siswa dalam melatih kemampuan berpikir kritis khususnya pada materi teori kinetik gas, dimana materi ini tidak hanya dapat disampaikan dalam bentuk soal latihan melainkan diperlukan permasalahan yang bersifat kontekstual. Contoh perubahan konsep yang terjadi pada diri siswa terletak pada materi teori ekipartisi energi, dimana siswa beranggapan bahwa energi dalam yang dimiliki oleh semua molekul hanya dapat dihitung dengan persamaan $U=\frac{3}{2} k T$, padahal energi dalam suatu atom itu bergantung dari jumlah atom yang menyusun suatu molekul. Molekul yang terdiri dari satu atom tentu akan memiliki energi dalam yang berbeda dengan molekul yang terdiri dari dua atau bahkan lebih atom.

Perubahan konsep yang terlihat seperti contoh sebelumnya dapat terjadi karena proses pembelajaran yang berlangsung pada ketiga kelas eksperimen dari kegiatan awal sampai kegiatan akhir menunjukkan adanya latihan untuk membentuk kemampuan berpikir kritis khususnya untuk materi teori kinetik gas. Pemberian latihan untuk meningkatkan kemampuan berpikir kritis ini disesuaikan dengan LKS yang telah dirancang sebelumnya.

Kegiatan awal memberikan permasalahan yang bersifat konsteksual atau sering diamati oleh siswa yang berada pada fase orientasi. Siswa kemudian dituntut untuk menyampaikan pendapat yang mereka miliki tentang permasalahan yang telah diberikan, ini masuk ke dalam fase elisitasi gagasan. Pemberian kesempatan pada siswa untuk memberikan pendapat terhadap permasalahan yang ada akan memberikan rangsangan terhadap keterampilan berpikir kritis. Hal ini sesuai dengan hasil penelitian yang dilakukan oleh Sutrio et al (2018) yang menemukan bahwa pada saat presentasi (menyampaikan pendapat) hasil proyek mahasiswa saling bertanya dan berpendapat 
terhadap proyek yang dikerjakan oleh kelompok lainnya, sehingga muncul ide-ide dan gagasan kreatif baik dalam berpendapat, menanggapi pertanyaan, maupun memberikan pertanyaan timbal balik.

Fase selanjutnya adalah restrukturasi gagasan yaitu fase dimana guru akan menyampaikan materi secara umum yang berkaitan dengan pembelajaran untuk digunakan sebagai literasi pada saat siswa melakukan pengamatan dan diskusi kelompok. Fase aplikasi gagasan merupakan bagian dari model perubahan konseptual yang memberikan kesempatan kepada siswa untuk menerapkan konsep baru yang dimiliki melalui kegiatan percobaan maupun pengamatan melalui demonstrasi oleh guru. Guru dalam menjelaskan menggunakan LKS yang telah dibuat berdasarkan indikator kemampuan berpikir kritis yang terdiri dari permasalahan, hipotesis penelitian, hasil pengamatan, analisis data, pembahasan, dan kesimpulan. Kegiatan yang dilakukan pada fase ini akan melatih kemampuan berpikir kritis siswa karena menurut Johnson (2008) bahwa berpikir kritis adalah sebuah proses yang terarah dan jelas yang digunakan untuk mengambil keputusan, menganalisis asumsi, dan melakukan penelitian ilmiah (dalam Latifa et al. 2017). Kegiatan akhir yang dilakukan adalah mengajak siswa untuk meninjau kembali konsep-konsep yang dipelajari sebelumnya yang berada pada fase review perubahan gagasan. Rangkaian pembelajaran yang diterapkan pada ketiga kelas eksperimen menunjukkan terdapat proses untuk melatih kemampuan berpikir kritis karena kemampuan ini tidak akan berkembang apabila tidak dilatih secara berkelanjutan. Snyder (2008) menyatakan bahwa keterampilan berpikir kritis membutuhkan latihan, praktik, dan kesabaran.

Berdasarkan Gambar 2, terlihat perbedaan nilai rata-rata per indikator kemampuan berpikir kritis pada ketiga kelas eskperimen saat proses pembelajaran berlangsung. Siswa yang diajarkan dengan MPK Visual memiliki nilai rata-rata tertinggi pada indikator interpretasi, disebabkan karena pada saat proses pembelajaran berlangsung siswa diberikan ilustrasi-ilustrasi berupa gambar, animasi, maupun video pembelajaran yang membantu siswa dalam mengingat dan menerima materi pembelajaran dengan baik. Husein et al. (2015) menyatakan bahwa animasi yang ditampilkan kepada siswa dapat melatih logika berpikir siswa dalam menyelesaikan permasalahan-permasalahan fisika. Pembelajaran Visual dapat pula menumbuhkan minat siswa dan dapat memberikan hubungan antara isi materi pelajaran dengan dunia nyata (kontekstual) (Munandar et al. 2018). Pembelajaran berbantuan simulasi komputer (visual) terbukti dapat meningkatkan keterampilan berpikir kritis siswa (Herayanti \& Habibi, 2015). Siswa akan cenderung lebih lama mengingat sesuatu yang dilihat dibandingkan dengan apa yang mereka dengar.

Siswa yang diajarkan dengan MPK Auditori memiliki nilai rata-rata tertinggi pada indikator menjelaskan, hal tersebut disebabkan karena pada saat proses pembelajaran berlangsung guru berusaha menyampaikan materi secara detail berkaitan dengan hubungan besaran atau konsep yang dipelajari. Penyampaian materi secara auditori di dalam kelas menyebabkan siswa akan terlatih untuk berpendapat atau menjawab pertanyaan-pertanyaan yang diberikan. Hasil tersebut didukung oleh penelitian yang dilakukan oleh Fitriyani (2017) yang menyatakan bahwa siswa dengan tipe gaya auditori akan lebih memahami pelajaran jika guru menjelaskan pelajaran atau materi dengan baik dan jelas. Proses inilah yang membuat siswa pada kelas MPK gaya auditori memiliki nilai ratarata tertinggi pada indikator menjelaskan. 
Siswa yang diajarkan dengan MPK Kinestetik memiliki nilai rata-rata tertinggi pada indikator analisis, hal tersebut disebabkan karena pada saat proses pembelajaran berlangsung guru memfasilitasi siswa untuk melakukan percobaan sederhana yang bertujuan untuk melatih kemampuan siswa dalam membandingkan antara fenomena sederhana yang mereka amati dengan konsep fisika yang sedang dipelajari di dalam kelas. Kegiatan secara langsung seperti melakukan percobaan sederhana di dalam proses pembelajaran menurut Aminullah (2017) dapat memberikan kesempatan kepada siswa untuk melakukan pengamatan dengan segenap indera yang mereka miliki dan menganalisis hasil yang didapatkan. Tentunya dengan cara ini menyebabkan siswa akan terbiasa untuk melatih kemampuan menganalisis terutama yang berkaitan dengan permasalahan yang sedang mereka hadapi. Model perubahan konseptual secara umum menekankan pembelajaran kepada siswa dan menjadikan guru sebagai fasilisator pembelajaran. Pebriyanti et al. (2015) menyatakan bahwa dalam pembelajaran perubahan konseptual guru lebih banyak berperan sebagai fasilisator, negoisator, dan konfrontator. Kondisi inilah yang membantu siswa dalam mengembangkan kemampuan berpikir kritis khususnya dalam belajar teori kinetik gas.

\section{PENUTUP}

Berdasarkan hasil analisis data dan pembahasan, dapat disimpulan bahwa tingkat kemampuan berpikir kritis siswa SMA saat proses pembelajaran teori kinetik gas dengan model perubahan konseptual ditinjau dari gaya belajar termasuk ke dalam kategori sedang dengan nilai sebesar 70,87. Beberapa saran yang ingin diajukan untuk penelitian selanjutnya yaitu memperhatikan alokasi waktu saat proses belajar mengajar berlangsung agar sesuai dengan tujuan pembelajaran yang diharapkan dan lebih banyak menggunakan observer agar data penilaian saat proses pembelajaran bisa lebih akurat.

\section{REFERENSI}

Aji, C. dan Dasari, D. 2009. Desain Faktorial Fraksional $2^{k-p}$ serta Analisisnya Berbasis Web. Makalah dipresentasikan pada Seminar Nasional Pendidikan Matematika FPMIPA UPI, Bandung.

Aminullah. 2017. Hubungan antara Keterlaksanaan Praktikum IPA dan Motivasi Belajar dengan Hasil Belajar IPA Siswa Kelas VIII SMP Negeri di Kabupaten Enrekang. Program PascaSarjana. Universitas Negeri Makassar. Makassar.

Facione, P. A. 2011. Critical Thinking: What It Is and Why It Counts. Milbrae: California Academic Press (pp 1-27).

Fatimah, N., Gunawan, G., \& Wahyudi, W. (2017). Pembelajaran Berbasis Masalah Dengan Strategi Konflik Kognitif Terhadap Penguasaan Konsep Dan Kemampuan Berpikir Kritis Fisika Siswa Kelas XI SMKN 1 Lingsar Tahun Pelajaran 2015/2016. Jurnal Pendidikan Fisika dan Teknologi, 2(4), 183-190.

Fitriyani. 2017. Gaya Belajar Siswa yang Memiliki Nilai Akademik Tinggi dan Rendah Kelas VII SMPN 1 Colomadu Tahun Ajaran 2016/2017. Fakultas Keguruan dan Ilmu Pendidikan. Universitas Muhammadiyah Surakarta. Surakarta.

Gunawan. (2017). Keterampilan Berpikir dalam Pembelajaran Sains. Mataram: Arga Puji Press.

Gredler, M. E. 2011. Learning and Instruction Ed.6. Jakarta: Kencana Prenada Media Grup.

Herayanti, L., \& Habibi, H. (2017). Model Pembelajaran Berbasis Masalah Berbantuan Simulasi Komputer untuk Meningkatkan Keterampilan 
Berpikir Kritis Calon Guru Fisika. Jurnal Pendidikan Fisika dan Teknologi, 1(1), 61-66.

Husein, S., Herayanti, L., \& Gunawan, G. (2017). Pengaruh Penggunaan Multimedia Interaktif Terhadap Penguasaan Konsep dan Keterampilan Berpikir Kritis Siswa pada Materi Suhu dan Kalor. Jurnal Pendidikan Fisika dan Teknologi, 1(3), 221-225.

Karim, N. Kemampuan Berpikir Kritis Siswa dalam Pembelajaran Matematika dengan Menggunakan Model Jucama di Sekolah Menengah Pertama. Jurnal Pendidikan Matematika, 3(1), 92-104.

Latifa, R. A. L., Verawati, N. N. S., dan Harjono, A. 2017. Pengaruh Model Learning Cycle 5E (Engage, Explore, Explain, Elaboration, \& Evaluate) terhadap Kemampuan Berpikir Kritis Peserta Didik Kelas X MAN 1 Mataram. Jurnal Pendidikan Fisika dan Teknologi, 3(1), 61-67.

Makhrus, M. 2018. Validitas Model Pembelajaran Conceptual Change Model with Cognitive Conflict Approach. Jurnal Ilmiah Profesi Pendidikan. 3(1), 62-66.

Munandar, H., Sutrio, dan Taufik, M. 2018. Pengaruh Model Pembelajaran Berbasis Masalah Berbantuan Media Animasi terhadap Kemampuan Berpikir Kritis dan Hasil Belajar Fisika Siswa SMAN 5 Mataram Tahun Ajaran 2016/2017. Jurnal Pendidikan Fisika dan Teknologi, 4(1), 111-120.

Pebriyanti, D., Sahidu, H., dan Sutrio. 2015. Efektifitas Model Pembelajaran Perubahan Konseptual untuk Mengatasi Miskonsepsi Fisika pada Siswa Kelas X SMAN 1 Praya Barat Tahun Ajaran 2012/2013. Jurnal Pendidikan Fisika dan Teknologi, 1(1), 92-96.

Posner, G. J., Strike, K. A., Hewson, P. W., dan Gertzog, W. A. 1982. Accommodation of a Scientific
Conception: Toward a Theory of Conceptual Change. Science Education Vol. 66 (2), 211-227.

Purwanto, M. N. 1992. Psikologi Pendidikan. Bandung: PT. Remaja Rosdakarya.

Rohman, M. dan Amri, S. 2012. Manajemen Pendidikan: Analisis dan Solusi terhadap Kinerja Manajemen Kelas dan Strategi Pengajaran yang Efektif. Jakarta: PT. Prestasi Pustakaraya.

Snyder, L. G. \& Snyder, M. J. 2008. Teaching Critical Thinking and Problem Solving Skills. The Delta Pi Epsilon Journal. Vol.L, No. 2, Spring/Summer, 2008 (pp 90-99).

Sugiyono. 2013. Metode Penelitian Pendidikan: Pendekatan Kuantitatif, Kualitatif, dan $R \& D$. Bandung: Penerbit Alfabeta.

Sutrio, S., Gunawan, G., Harjono, A., \& Sahidu, H. (2018). Pengembangan Bahan Ajar Fisika Eksperimen Berbasis Proyek Untuk Meningkatkan Keterampilan Berpikir Kritis Calon Guru Fisika. Jurnal Pendidikan Fisika dan Teknologi, 4(1), 131-140.

Vegisari. 2015. Pengaruh Remidiasi Berbentuk Peningkatan Kemampuan Verbal terhadap Penurunan Miskonsepsi Teori Kinetik Gas di SMA. Program Sarjana. Universitas Tanjungpura. Pontianak. 